\title{
Common bacterial responses in six ecosystems exposed to 10 years of elevated atmospheric carbon dioxide
}

John Dunbar, ${ }^{1}$ Stephanie A. Eichorst, ${ }^{1}$

La Verne Gallegos-Graves, ${ }^{1}$ Shannon Silva, ${ }^{1}$ Gary Xie, ${ }^{1}$ N. W. Hengartner, ${ }^{2}$ R. David Evans, ${ }^{3}$ Bruce A. Hungate, ${ }^{4,5}$ Robert B. Jackson, ${ }^{6,7}$ J. Patrick Megonigal, ${ }^{8}$ Christopher W. Schadt, ${ }^{9}$ Rytas Vilgalys, ${ }^{7}$ Donald R. Zak ${ }^{10,11}$ and Cheryl R. Kuske ${ }^{1 *}$ ${ }^{1}$ Bioscience Division, Los Alamos National Laboratory, Los Alamos, NM, USA.

${ }^{2}$ Computer, Computational, and Statistical Sciences Division, Los Alamos National Laboratory, Los Alamos, NM, USA.

${ }^{3}$ School of Biological Sciences, Washington State University, Pullman, WA 99164, USA.

${ }^{4}$ Department of Biological Sciences, ${ }^{5}$ Merriam-Powell Center for Environmental Research, Northern Arizona University, Flagstaff, AZ 86011, USA.

${ }^{6}$ Department of Biology, ${ }^{7}$ Nicholas School of the Environment, Duke University, Durham, NC 27708, USA.

${ }^{8}$ Smithsonian Environmental Research Center, Washington, DC 20013, USA.

${ }^{9}$ Biosciences Division, Oak Ridge National Laboratory, Oak Ridge, TN 37831, USA.

${ }^{10}$ School of Natural Resources \& Environment, ${ }^{11}$ Department of Ecology and Evolutionary Biology, University of Michigan, Ann Arbor, MI 48109, USA.

\section{Summary}

Six terrestrial ecosystems in the USA were exposed to elevated atmospheric $\mathrm{CO}_{2}$ in single or multifactorial experiments for more than a decade to assess potential impacts. We retrospectively assessed soil bacterial community responses in all six-field experiments and found ecosystem-specific and common patterns of soil bacterial community response to elevated $\mathrm{CO}_{2}$. Soil bacterial composition differed greatly across the six ecosystems. No common effect of elevated atmospheric $\mathrm{CO}_{2}$ on bacterial biomass,

Received 22 April, 2011; accepted 15 December, 2011. *For correspondence. E-mail kuske@lanl.gov; Tel. (+1) 505665 4800; Fax (+1) 5056653024 . richness and community composition across all of the ecosystems was identified, although significant responses were detected in individual ecosystems. The most striking common trend across the sites was a decrease of up to 3.5 -fold in the relative abundance of Acidobacteria Group 1 bacteria in soils exposed to elevated $\mathrm{CO}_{2}$ or other climate factors. The Acidobacteria Group 1 response observed in exploratory $16 S$ rRNA gene clone library surveys was validated in one ecosystem by 100 -fold deeper sequencing and semiquantitative PCR assays. Collectively, the 16S rRNA gene sequencing approach revealed influences of elevated $\mathrm{CO}_{2}$ on multiple ecosystems. Although few common trends across the ecosystems were detected in the small surveys, the trends may be harbingers of more substantive changes in less abundant, more sensitive taxa that can only be detected by deeper surveys.

\section{Introduction}

Understanding how soil microbial responses to climate change differ among terrestrial ecosystems is central to predicting regional and global trends. Changes in soil microbial communities can occur as a direct response to variables associated with climate change (e.g. temperature, water availability, nitrogen deposition, concentrations of trace gases like ozone) or as responses to altered plant primary productivity under elevated atmospheric $\mathrm{CO}_{2}$. Primary producers in diverse ecosystems have shown common responses to elevated $\mathrm{CO}_{2}$. Higher short-term productivity, lower transpiration, increased carbon inputs to soil through litter fall and root activity (Karnosky, 2003; Ainsworth and Long, 2005; Ainsworth and Rogers, 2007; Lukac et al., 2009), and altered nutritional quality of plant litter or root exudates are common responses of $\mathrm{C} 3$ plants (Zak et al., 1993; Cotrufo et al., 1994; Couteaux et al., 1995; Randlett et al., 1996; King et al., 2001; Weatherly et al., 2003; Hall et al., 2005; Haase et al., 2007; Parsons et al., 2008; Phillips et al., 2009). However, a corresponding picture of common patterns in soil microbial community responses to climate change variables has not yet emerged. Microbial responses to elevated atmospheric $\mathrm{CO}_{2}$ have thus far been examined in single ecosystem 
Table 1. Description of the six experimental ecosystems. ${ }^{a}$

\begin{tabular}{|c|c|c|c|c|}
\hline Ecosystem & Treatments and other factors & $\begin{array}{l}\text { Total time } \\
\text { (years) }\end{array}$ & $\begin{array}{l}\text { Field } \\
\text { reps }\end{array}$ & Number of $16 \mathrm{~S}$ rRNA sequences per survey \\
\hline $\begin{array}{l}\text { Wisconsin (WI) } \\
\quad \text { aspen plantation }\end{array}$ & $\begin{array}{l}\text { 1) Ambient } \\
\text { 2) Elev. } \mathrm{CO}_{2}(534 \text { p.p.m.) } \\
\text { 3) Elev. } \mathrm{CO}_{2}+\mathrm{O}_{3}(0.05 \text { p.p.m.) } \\
\text { 4) } \mathrm{O}_{3} \text { (0.05 p.p.m.) }\end{array}$ & 9 & 3 & $\begin{array}{l}\text { 1) } 254,270,333,295,297 \\
\text { 2) } 291,282,271,265 \\
\text { 3) } 220,248,226 \\
\text { 4) } 261,254,248\end{array}$ \\
\hline $\begin{array}{l}\text { North Carolina (NC) } \\
\text { loblolly pine plantation }^{\mathrm{b}}\end{array}$ & $\begin{array}{l}\text { 1) Ambient } \\
\text { 2) Elev. } \mathrm{CO}_{2}(570 \text { p.p.m.) } \\
\text { 3) Ambient }+\mathrm{N}^{\mathrm{c}}\end{array}$ & 11 & 3 & $\begin{array}{l}\text { 1) } 274,206,242,335,238,239,251 \\
\text { 2) } 282,201,280,323,247,263,241,230 \\
\text { 3) } 359,368,360 \\
\text { 4) } 359,338,370\end{array}$ \\
\hline $\begin{array}{l}\text { Tennessee (TN) } \\
\text { sweetgum plantation }^{\mathrm{b}}\end{array}$ & $\begin{array}{l}\text { 4) Elev. } \mathrm{CO}_{2}+\mathrm{N} \\
\text { 1) Ambient } \\
\text { 2) Elev. } \mathrm{CO}_{2}(545 \text { p.p.m.) } \\
\text { Factor: Depth }(0-5,5-15,15-30 \mathrm{~cm})\end{array}$ & 9 & 2 & $\begin{array}{l}\text { 1) }(282,262)(229,196)(239,287) \\
\text { 2) }(240,259)(292,239)(284,196)\end{array}$ \\
\hline $\begin{array}{l}\text { Florida (FL) Scrub } \\
\text { oak/palmetto }\end{array}$ & $\begin{array}{l}\text { 1) Ambient } \\
\text { 2) Elev. } \mathrm{CO}_{2}(700 \text { p.p.m.) } \\
\text { Factor: Depth }(0-10,10-30 \mathrm{~cm})\end{array}$ & 11 & 3 & $\begin{array}{l}\text { 1) }(315,327,340)(332,304,340) \\
\text { 2) }(314,237,324)(308,235,339)\end{array}$ \\
\hline Maryland (MD) tidal marsh ${ }^{d}$ & $\begin{array}{l}\text { 1) Ambient } \\
\text { 2) Elev. } \mathrm{CO}_{2}(680-705 \text { p.p.m.) }\end{array}$ & 21 & 5 & $\begin{array}{l}\text { 1) } 307,235,185,295,294 \\
\text { 2) } 212,235,278,300,270\end{array}$ \\
\hline $\begin{array}{l}\text { Nevada (NV) Biological } \\
\text { soil crust/creosote } \\
\text { bush root zone }\end{array}$ & $\begin{array}{l}\text { 1) Ambient } \\
\text { 2) Elev. } \mathrm{CO}_{2} \text { ( } 550 \text { p.p.m.) } \\
\text { Factor: Ground cover }\end{array}$ & 10 & 3 & $\begin{array}{l}\text { 1) } \mathrm{B}_{-}-(274,275,275), \mathrm{C}-(203,257,184) \\
\text { 2) } \mathrm{B}-(243,312,187,248,288,280), \mathrm{C}-(243,227,168)\end{array}$ \\
\hline
\end{tabular}

a. Additional information is provided in Table S1.

b. Free Air Carbon Dioxide Enrichment design.

c. $\mathrm{N}$ fertilization $\left(\mathrm{NH}_{4}\right)_{2} \mathrm{NO}_{3}$, was supplied in a single annual dose $\left(11.2 \mathrm{~g} \mathrm{~m}^{-2}\right.$ per year).

d. Open Top Chamber design.

e. 'B' - creosote bush root zone; 'C' - biological soil crust. Soil samples were collected below the drip line of randomly selected creosote bushes and from the biological soil crusts.

studies (Zak et al., 2000; Rustad et al., 2001; Treseder, 2004; Kelly et al., 2010). Concerted studies of multiple ecosystems can conceivably reveal subtle trends that might otherwise be obscured by the high variability often observed in single ecosystem studies.

We initiated a concerted analysis of soil bacterial communities in six elevated atmospheric $\mathrm{CO}_{2}$ field experiments in the USA. The field experiments represent different ecosystems: three tree plantations and three natural ecosystems (Tables 1 and S1). The dominant species at the three plantation sites were trembling aspen (Populus tremuloides; Rhinelander, Wisconsin), loblolly pine (Pinus taeda; Durham, North Carolina), and sweetgum (Liquidambar styraciflua; Oak Ridge, Tennessee). The natural desert site (Mercury, Nevada) had a patchy plant cover of creosote bush (Larrea tridentada), and perennial bunchgrasses (Lycium spp. and Ambrosia dumosa), with cyanobacterial biological soil crusts that colonize the interspaces between the sparse plant cover. These four sites used a Free-Air Carbon Dioxide Enrichment (FACE) design. The scrub oak/palmetto (Quercus myrtifolia/Serenoa repens; Cape Canaveral, Florida) is a brackish coastal site. The brackish tidal marsh (Chesapeake Bay, Maryland) has a dominant cover of Spartina and other marsh grasses. These two sites used an Open Top Chamber (OTC) design. Each field site included replicate ambient and elevated $\mathrm{CO}_{2}$ treatments (340-395 p.p.m. ambient versus 534-700 p.p.m. elevated $\mathrm{CO}_{2}$; Table 1). Every ecosystem exhibited significant increases in net primary production under elevated $\mathrm{CO}_{2}$ (Zak et al., 1993; Couteaux et al., 1995; Smith et al., 2000; Weatherly et al., 2003; Ainsworth and Long, 2005; Nowak et al., 2004; Hall et al., 2005; Heath et al., 2005; Housman et al., 2006; Iversen et al., 2008; Parsons et al., 2008). Increased carbon inputs into soil under elevated $\mathrm{CO}_{2}$ occur through greater primary productivity, via plant litter deposition (Karnosky, 2003; Lichter et al., 2008; Hoosbeek and Scarascia-Mugnozza, 2009), root growth and turnover (King et al., 2001; Larson et al., 2002; Matamala et al., 2003; Norby et al., 2004; Godbold et al., 2006; Lukac et al., 2009), root exudates (Cheng, 1999; Paterson et al., 2008; Pendall et al., 2008; Phillips et al., 2009), and changes in root depth distributions (Iversen, 2010). We sought to determine whether the aggregate changes in primary production induced common soil bacterial responses among ecosystems.

We performed exploratory analyses with 76 soil samples to assess changes in the size and composition of the soil bacterial communities. Given the limited size of our surveys (168 to 338 sequences per sample), detecting responses for individual taxa was constrained to a handful of the most abundant taxa at each site. Furthermore, the spatial scale for sampling inevitably restricted our analyses to the taxa present in multiple sites, which may be the least sensitive to small changes in biotic and abiotic variables. Our exploratory study was therefore conservative. Nonetheless, in every ecosystem we found responses to decade-long ecosystem exposure to 


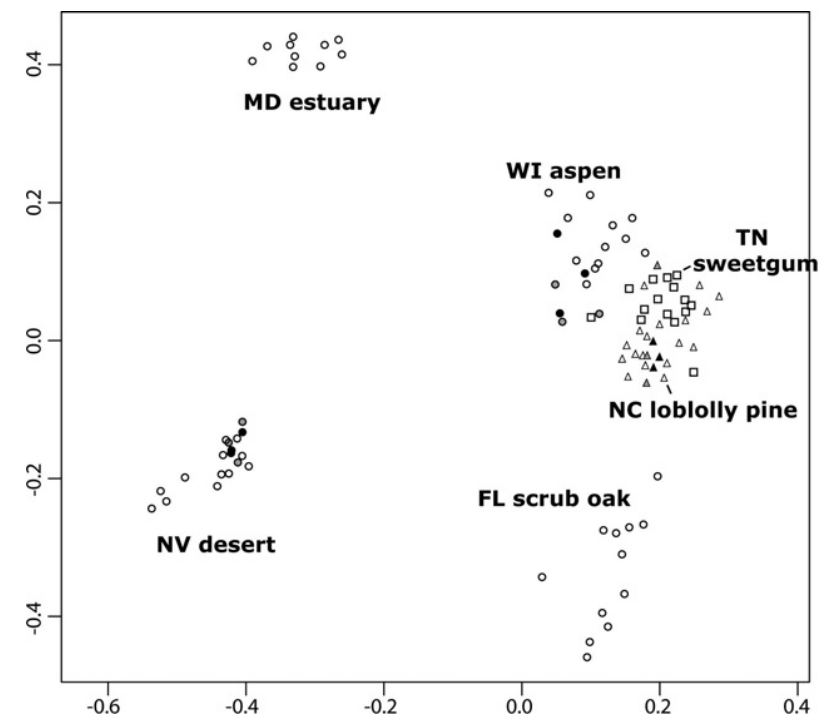

Fig. 1. Similarity of soil microbial communities in six ecosystems. The plot shows nonmetric multidimensional scaling of Bray-Curtis values computed from OTU OT $_{97}$ presence/absence profiles of $9716 \mathrm{~S}$ rRNA gene clone libraries. Stress value $=13.9$. Similar results were obtained using relative abundance instead of presence/absence data. The black-filled symbols and grey-filled symbols represent surveys from MoBio DNA extracts and matching FastDNA extracts, respectively, used to evaluate DNA extraction bias.

elevated $\mathrm{CO}_{2}$. This paper does not attempt to detail the responses in each ecosystem; instead we focus on general patterns across the ecosystems.

\section{Results}

The results are organized in four sections. The first section describes the general similarity of the bacterial communities in the six ecosystems as measured by $16 \mathrm{~S}$ rRNA clone library sequences. The second section describes evidence of community responses to climate factors using composite metrics - biomass, bacterial community richness and composition. The third section describes the responses of individual taxa. The fourth section describes a trend analysis to discover common taxon responses among the ecosystems and an associated validation effort at one of the six sites.

\section{Soil bacterial communities across the ecosystems were very different, but some common taxa occurred}

The level of similarity of bacterial communities generally corresponded with degree of similarity in measured soil characteristics (Fig. 1, Table S2). Each of the 97 16S rRNA gene clone library surveys created in this study for comparison of community composition contained 168338 clones (average $=271$ ). The libraries collectively represented 34 to 6980 taxa, depending on the taxonomic level examined (i.e. OTU $\mathrm{OT}_{70}$ to OTU $\mathrm{OT}_{97}$ ). Bacterial communi- ties in soils from the WI aspen, NC pine and TN sweetgum sites were the most similar (based on species-level profiles), although the sites have large differences in soil type, tree species, mean annual temperature and spatial separation (about 69-1200 km) (Fig. 1). The natural NV desert, MD marsh and FL scrub oak/palmetto ecosystems were distinct. There were no species-level (OTU ${ }_{97}$ ) taxa common to all six ecosystems, but 12 of the 6980 species-level OTUs were detected in five ecosystems. At coarser taxonomic levels, community similarity among all ecosystems increased, as expected. In ambient $\mathrm{CO}_{2}$ surface soils, 17 of 769 total taxa (from all samples) at the family/genus level $\left(\mathrm{OTU}_{85}\right)$ were detected in all six ecosystems representing the following: two Acidobacteria families from subdivisions 1 and 3, three Actinobacteria families (Mycobacteriaceae, Thermomonosporaceae, Conexibacteraceae), a Bacteriodetes family (Chitinophagaceae), eight Proteobacteria families and a Verrucomicrobia group (Table S3).

\section{Significant changes in general community metrics (biomass, richness and beta diversity) were sparse and ecosystem-specific}

Soil biomass. Elevated $\mathrm{CO}_{2}$ treatments showed a small and inconsistent effect on total biomass (Fig. 2A, Table S5). Extracted soil DNA was used as a proxy for biomass. In surface soils, DNA increased $0.1-30 \%$ in four elevated $\mathrm{CO}_{2}$ treatment comparisons, but decreased 8-51\% in the other four cases (Fig. 2A and Table S4). Only the two largest changes - a $30 \%$ increase in the TN sweetgum soils and a $51 \%$ decrease in FL scrub oak/ palmetto soils - were statistically significant $(P=0.092$ and $P=0.051$ respectively). Thus, no consistent trend was detected for the impact of elevated $\mathrm{CO}_{2}$ on total soil biomass in surface soils. Slightly larger changes ranging from $50 \%$ to $270 \%$ occurred in soil biomass in response to soil depth (examined at two sites) or nitrogen fertilization (examined at one site) (Fig. 2A and Table S4).

Bacterial biomass. The influence of elevated $\mathrm{CO}_{2}$ exposure on bacterial biomass, estimated by qPCR of $16 \mathrm{~S}$ rRNA genes, was generally similar to the effects on total soil biomass (Fig. 2B, Table S4). The estimated copy number of bacterial $16 \mathrm{~S}$ rRNA genes in soil ranged from $1.8 \times 10^{8}$ to $3.4 \times 10^{10}$. Elevated $\mathrm{CO}_{2}$ treatments did not substantially alter bacterial biomass in surface soils ( 0 to 5 or $10 \mathrm{~cm}$ ). The $16 \mathrm{~S}$ rRNA gene copy number increased in half the cases by $4-10 \%$, and decreased in the other cases by $26-49 \%$. Only the $49 \%$ decrease in surface soil with elevated $\mathrm{CO}_{2}$ at the $\mathrm{FL}$ scrub oak/palmetto site was significant $(P=0.084)$. Larger declines of 2.4- to 9.7-fold occurred with soil depth or with nitrogen fertilization (Fig. 2B and Table S4). 
A

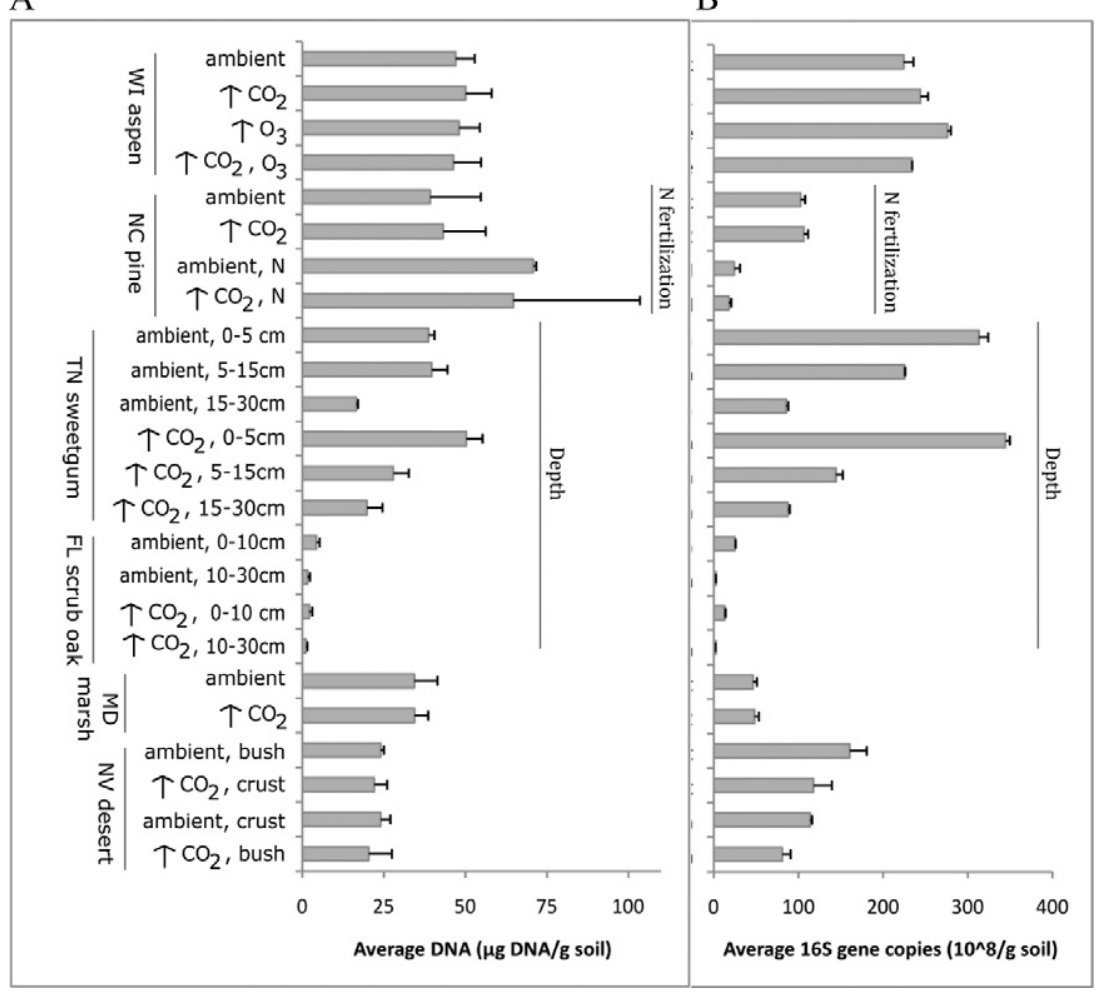

Fig. 2. Estimated soil and bacterial biomass in soil samples from six ecosystems.

A. Total soil (microbial) biomass as represented by extracted DNA.

B. Bacterial biomass estimated by qPCR of $16 \mathrm{~S}$ rRNA genes. Error bars are $95 \%$ confidence intervals.
Community richness. In one of six ecosystems, bacterial taxon richness increased under elevated $\mathrm{CO}_{2}$ (Table S5). At the WI aspen site, taxon richness increased $11-22 \%$ at various taxonomic levels $\left(\mathrm{OTU}_{70}\right.$ to $\mathrm{OTU}_{90}, P<0.1$ ) in plots exposed to elevated $\mathrm{CO}_{2}$ or a combination of elevated $\mathrm{CO}_{2}$ and ozone (Fig. 3). The WI aspen site had the highest magnitude of changes in richness among the six ecosystems.

Community composition. Three of five ecosystems (the TN sweetgum site was not included in this analysis because of insufficient replicates) showed evidence of treatment effects on community similarity. The similarity of communities from treated plots versus ambient plots was initially compared using UniFrac tests for homogeneity. However, in all ecosystems, significant differences occurred among replicates (data not shown), demonstrating that soil heterogeneity and treatment effects could not be distinguished by UniFrac permutation tests. As an alternative, we evaluated treatment effects based on $t$-tests of the mean beta diversity among samples within treatments. The MD marsh soil bacterial communities showed the clearest evidence of elevated atmospheric $\mathrm{CO}_{2}$ impacts on beta diversity. At five taxonomic levels $\left(\mathrm{OTU}_{70}\right.$ to $\mathrm{OTU}_{90}$; Table S6), soil communities from elevated $\mathrm{CO}_{2}$ plots were significantly more similar to one another than communities from ambient plots (Fig. 4), suggesting a homogenizing effect of selection at this site.
The results were obtained using the quantitative version of the Bray-Curtis index, which gives abundant taxa the most weight. In the qualitative (presence-absence) BrayCurtis index, taxa with lower abundance exert a larger effect. With the qualitative index, three ecosystems

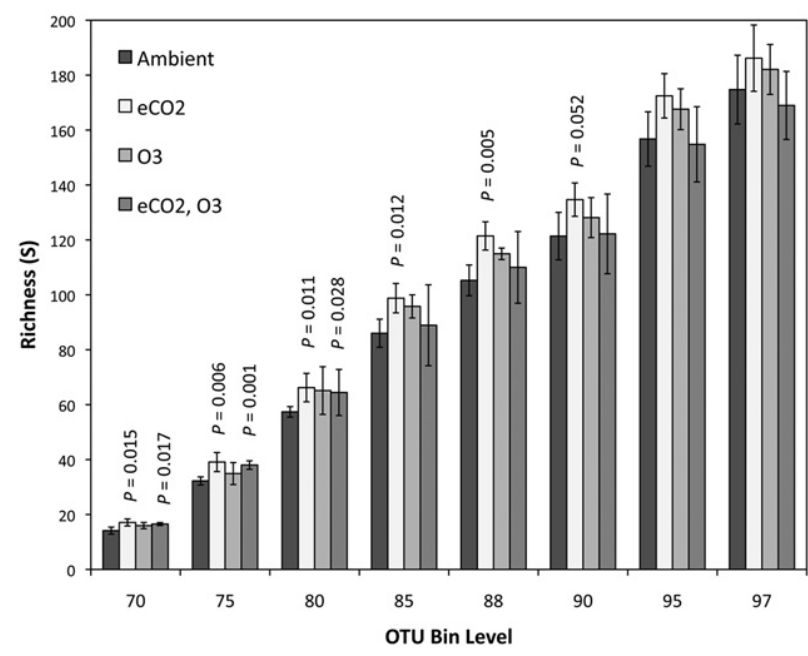

Fig. 3. Average richness of soil bacterial community surveys from treatments at the $\mathrm{WI}$ aspen site. Bars indicate the mean richness (number of OTUs) among samples within each treatment. Error bars are $95 \%$ confidence intervals. $P$-values were obtained from $t$-tests of each treatment compared with the ambient condition. Only the $P$-values that remained significant after correcting for the false discovery rate at $P<0.1$ are shown. 


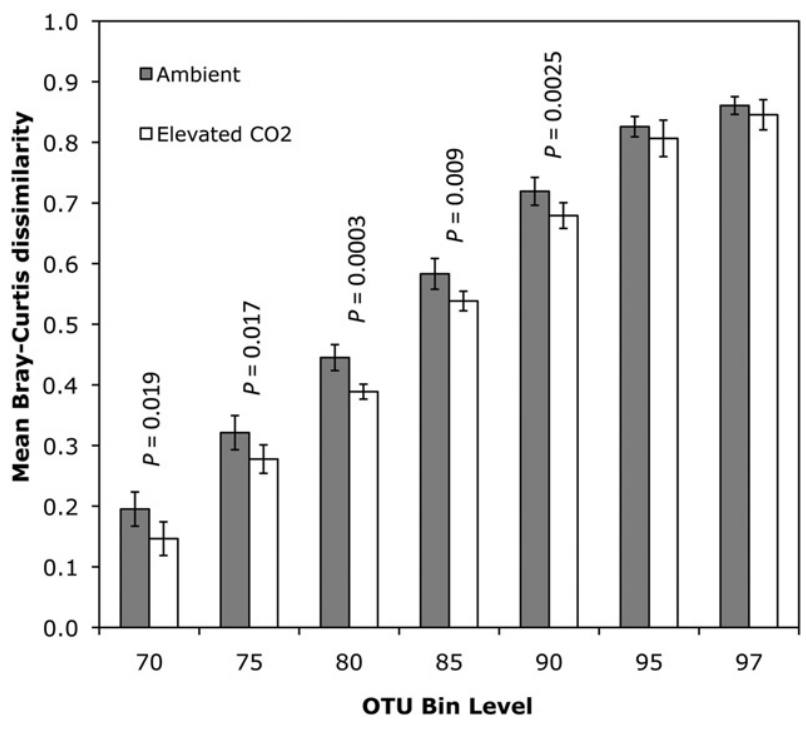

Fig. 4. Impact of elevated $\mathrm{CO}_{2}$ treatment on beta diversity of $\mathrm{MD}$ marsh soil bacterial communities. Bars indicate the mean beta diversity among samples within each treatment. Error bars are 95\% confidence intervals. showed significant elevated $\mathrm{CO}_{2}$ effects on community similarity. These were the WI aspen site, the NC pine site and the MD marsh site (Table S6). We did not observe a consistent pattern of communities becoming more similar under elevated $\mathrm{CO}_{2}$ compared with communities from ambient plots.

Collectively, the results show that significant changes in bacterial biomass, community richness, and community composition under elevated $\mathrm{CO}_{2}$ were sparse and ecosystem-specific. Although significant treatment effects were measured at individual sites, a decade of exposure to elevated $\mathrm{CO}_{2}$ had no significant common effect on bacterial biomass, community richness or community composition across the sites.

Individual taxa were screened for potentially significant, ecosystem-specific responses to treatment factors

Although community size and structure were generally resilient under elevated $\mathrm{CO}_{2}$ (results above), significant responses may have occurred among individual taxa. Individual taxa with twofold or greater changes in abundance under elevated $\mathrm{CO}_{2}$ treatments were detected in every ecosystem (Table 2 ). We restricted the analysis to adequately sampled taxa - i.e. taxa detected in at least

Table 2. Percentage of bacterial taxa with two-fold or greater changes in relative abundance and $P$-values less than 0.05 .

\begin{tabular}{|c|c|c|c|c|c|c|c|c|}
\hline \multirow[b]{2}{*}{ Site } & \multirow[b]{2}{*}{ Treatment comparison } & \multicolumn{7}{|c|}{ Percentage of testable taxa showing significant change ${ }^{a}$} \\
\hline & & $\mathrm{OTU}_{70}$ & $\mathrm{OTU}_{75}$ & $\mathrm{OTU}_{80}$ & $\mathrm{OTU}_{85}$ & $\mathrm{OTU}_{90}$ & $\mathrm{OTU}_{95}$ & $\mathrm{OTU}_{97}$ \\
\hline \multicolumn{9}{|l|}{ Elevated $\mathrm{CO}_{2}$} \\
\hline \multirow[t]{3}{*}{ WI aspen } & $\uparrow \mathrm{CO}_{2}$ vs Ambient & & & $4.7(2)$ & $2.1(1)$ & \multirow[t]{3}{*}{$2.3(1)$} & $7.7(1)$ & \\
\hline & $\uparrow \mathrm{O}_{3}$ vs Ambient & $7.7(1)$ & $4.5(1)$ & $3.4(1)$ & $3.6(1)$ & & & \\
\hline & $\uparrow \mathrm{CO}_{2}, \mathrm{O}_{3}$ vs Ambient & & $4.3(1)$ & $7.4(2)$ & $3.8(1)$ & & & \\
\hline \multirow[t]{2}{*}{ NC pine } & $\uparrow \mathrm{CO}_{2}$ vs Ambient & & $3.3(1)$ & & & \multirow{3}{*}{$\begin{array}{l}1.3(1) \\
3.4(1)\end{array}$} & $4(3)$ & \multirow[t]{2}{*}{$8.5(4)$} \\
\hline & $\uparrow \mathrm{CO}_{2}, \mathrm{~N}$ vs $\uparrow \mathrm{N}$, Ambient & & & & & & $5.6(1)$ & \\
\hline \multirow[t]{3}{*}{ TN sweetgum } & $\uparrow \mathrm{CO}_{2}$ vs Ambient, $0-5 \mathrm{~cm}$ & & & $4.3(1)$ & $4(1)$ & & & \\
\hline & $\uparrow \mathrm{CO}_{2}$ vs Ambient, $5-15 \mathrm{~cm}$ & & $5(1)$ & & & \multirow{4}{*}{$4.8(1)$} & & \\
\hline & $\uparrow \mathrm{CO}_{2}$ vs Ambient, $15-30 \mathrm{~cm}$ & $20(2)$ & & $9.5(2)$ & $9.5(2)$ & & $13.3(2)$ & \\
\hline \multirow[t]{2}{*}{ FL scrub oak } & $\uparrow \mathrm{CO}_{2}$ vs Ambient, $0-10 \mathrm{~cm}$ & & & & \multirow{4}{*}{$\begin{array}{l}2.5(1) \\
3.8(1)\end{array}$} & & $13.3(2)$ & \multirow[t]{2}{*}{$9.1(1)$} \\
\hline & $\uparrow \mathrm{CO}_{2}$ vs Ambient, $10-30 \mathrm{~cm}$ & & $7.7(1)$ & $6.3(1)$ & & & $10(1)$ & \\
\hline MD marsh & $\uparrow \mathrm{CO}_{2}$ vs Ambient & & & & & $2.9(1)$ & $3.7(1)$ & $5.3(1)$ \\
\hline NV bush & $\uparrow \mathrm{CO}_{2}$ vs Ambient & & & & & $3.4(1)$ & $5.6(1)$ & \\
\hline \multicolumn{9}{|c|}{ Nitrogen fertilization } \\
\hline \multirow[t]{3}{*}{ NC pine } & $\uparrow \mathrm{CO}_{2}, \mathrm{~N}$ vs Ambient & $16.7(2)^{b}$ & $18.2(4)$ & $10.3(3)$ & $10.5(4)$ & $5.6(2)$ & $15.8(3)$ & $9.1(1)$ \\
\hline & $\uparrow \mathrm{N}$, Ambient vs Ambient & $16.7(2)$ & $17.4(4)$ & $15.6(5)$ & $8.1(3)$ & $10.3(4)$ & $4.5(1)$ & \\
\hline & $\uparrow \mathrm{CO}_{2}, \mathrm{~N}$ vs $\uparrow \mathrm{CO}_{2}$ & $8.3(1)$ & $13(3)$ & $10(3)$ & $12.2(5)$ & $13.5(5)$ & $4.2(1)$ & $7.7(1)$ \\
\hline \multicolumn{9}{|l|}{ Depth } \\
\hline \multirow[t]{2}{*}{ TN sweetgum } & \multirow{2}{*}{$\begin{array}{l}\text { Ambient } 0-5 \text { vs } 15-30 \mathrm{~cm} \\
\uparrow \mathrm{CO}_{2} 0-5 \text { vs } 15-30 \mathrm{~cm}\end{array}$} & & & $4.2(1)$ & $3.6(1)$ & & $5.3(1)$ & \\
\hline & & $27.3(3)$ & $15.8(3)$ & $20(4)$ & $17.6(3)$ & $11.8(2)$ & $30.8(4)$ & $20(1)$ \\
\hline \multirow[t]{2}{*}{ FL scrub oak } & Ambient $0-10$ vs $10-30 \mathrm{~cm}$ & $12.5(1)$ & $7.1(1)$ & $5.6(1)$ & $5.6(1)$ & $5.9(1)$ & $12.5(2)$ & \\
\hline & $\uparrow \mathrm{CO}_{2} 0-10$ vs $10-30 \mathrm{~cm}$ & $14.3(1)$ & $27.3(3)$ & $23.1(3)$ & $23.1(3)$ & $18.8(3)$ & $10(1)$ & $12.5(1)$ \\
\hline
\end{tabular}

a. Two criteria were used to define adequately sampled taxa as follows: (i) a taxon had to be detected in at least three replicate samples (or only two in the case of the TN sweetgum site) from each treatment and (ii) the taxon had to exhibit a variance $>0$ among replicate samples in relative abundance.

b. Values in parentheses are the number of taxa with twofold or greater changes in relative abundance and $P$-values $<0.05$.

$\square-$ table values $\geq 10$.

$\square-$ table values $\geq 5$.

Empty cells indicate no taxa occurred with significant, twofold or greater changes in relative abundance.

Published 2012. This article is a U.S. Government work and is in the public domain in the USA Environmental Microbiology, 14, 1145-1158 
three replicates from ambient and three replicates from elevated $\mathrm{CO}_{2}$ treatments (or two replicates per treatment at the TN sweetgum site) at each site. Although this criterion substantially reduced the number of useable taxa, it avoided the problematic use of missing data (zero counts). On average, each site had 21 OTUs (range = 275) suitable for analysis per taxonomic level per treatment comparison. At $P<0.05,45$ taxa (various taxonomic levels) with twofold or greater changes in abundance under elevated $\mathrm{CO}_{2}$ were identified among the six ecosystems from the 133 taxa tested (Table S7). On average, $2.7 \%$ of the adequately sampled taxa in each ecosystem showed significant responses to elevated $\mathrm{CO}_{2}$. In comparison, $11-12 \%$ of taxa were responsive to soil depth (examined at two sites) or nitrogen deposition (examined at one site).

It is possible that most of the taxa that appeared responsive under elevated $\mathrm{CO}_{2}$ were false positives that had low $P$-values by chance. After correcting for the false discovery rate with a $P$-value of 0.1 , only one group of Beta-proteobacteria from the $15-30 \mathrm{~cm}$ soil depth at the TN sweetgum site was significant (Table S7). However, application of the false discovery rate, which reduces the risk of false positives but increases the risk of false negatives, may be excessively stringent with these exploratory data. The combination of small sample sizes, substantial spatial heterogeneity and low replication weakens the resolving power and can obscure true positives. Thus, it is worthwhile to consider the taxa in Table S8 as candidate responsive taxa (i.e. possible indicator species) that may be corroborated by evidence in future field studies. We illustrate the excessive stringency of the false discovery rate below with 100-fold deeper pyrotag surveys.

Pyrotag surveys at the WI aspen site were conducted to validate observations from the exploratory clone library surveys. The pyrotag surveys used a different PCR primer set and sequencing technology, providing a measurement that was both higher quality and orthologous to the clone library surveys. A total of 31 737-75 663 16S rRNA gene sequences (about $400 \mathrm{nt}$ each) were obtained from each of three replicate soil samples from ambient plots and three replicate samples from plots under elevated $\mathrm{CO}_{2}$ (Table S9). The sequences were clustered into OTUs using a $97 \%$ sequence similarity threshold. Of the 1313 taxa that were consistently detected in all replicates, 93 taxa had $P$-values less than 0.05 . Seventy-five of these (about 6\% of total) showed twofold or greater changes in average relative abundance (Table S10). Of the 75 taxa, the relative abundance of 34 taxa increased 2- to 5-fold, while 41 taxa decreased 2- to 11-fold under elevated $\mathrm{CO}_{2}$. After applying the false discovery rate (FDR), none of the taxa were significant. However, if all of the taxa were false positives occurring by chance, as implied by the FDR results, the distribution of $P$-values from the 1313 total taxa would be uniformly distributed. The observed distribution was significantly different from a uniform distribution (chi-squared test and Kolmogorov-Smirnov test, $P<10^{-10}$ ) with far more low $P$-values (i.e. $P<0.1$ ) than expected by chance. Thus, application of the FDR is too stringent for this dataset. The set of 75 taxa may contain some false positives, but clearly there are many true, responsive taxa. Identifying exactly which taxa are true positives will require additional corroborating data.

\section{Some taxa do not have significant changes in abundance within a single site, but have a common, significant response pattern across sites}

Taxa with common response patterns to climate change treatments across sites were identified by a trend analysis. Taxa may exhibit significant trends across sites yet have non-significant responses within individual sites owing to local, mitigating ecological factors or to sampling artefacts. The trend analysis for each taxon involved up to 12 comparisons of ambient versus elevated $\mathrm{CO}_{2}$. For this analysis, we included only taxa that were detected in two or more replicates from ambient and from elevated $\mathrm{CO}_{2}$ conditions and present in four or more of the twelve test cases among ecosystems. Thus, the trend analysis was slightly less stringent in terms of consistent detection within sites, but was considerably more stringent in terms of detection across sites. Only 214 taxa (of 14716 total)

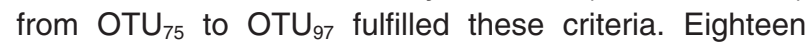
percent (39 of 214) of the taxa showed significant response trends $(P<0.1)$ (Table S12). The taxa belonged to eight phyla - Acidobacteria, Actinobacteria, Proteobacteria, Verrucomicrobia, Nitrospira, Firmicutes, OD1 and TM7 - and represent possible targets for further ecological analysis.

Acidobacteria Group 1 and Acidobacteria Group 2 taxa exhibited the most consistent and robust trends (Table 3). The Acidobacteria Group 1 taxa that showed significant trends included groups from the genus/species level $\left(\mathrm{OTU}_{95}\right)$ to the subdivision level $\left(\mathrm{OTU}_{75}\right)$ and were present in 4-10 of the 12 test cases of ambient soils versus soils under elevated $\mathrm{CO}_{2}$ (Table 3). Relative abundance of Acidobacteria Group 1 (at the subdivision level) under elevated $\mathrm{CO}_{2}$ conditions was reduced by an average of $25 \%$ across all the sites. Individual site responses ranged from a $9 \%$ increase to a $69 \%$ reduction (Table S8). Similarly, the average decline of Acidobacteria Group 2 was $18 \%$ across sites. Although the magnitude of these responses is small, taxa that demonstrate significant patterns across sites are noteworthy as possible indicators of broadly occurring but difficult to measure mechanistic phenomena.

The decline in Acidobacteria Group 1 was validated by pyrotag surveys and qPCR assays at the WI aspen site. In 

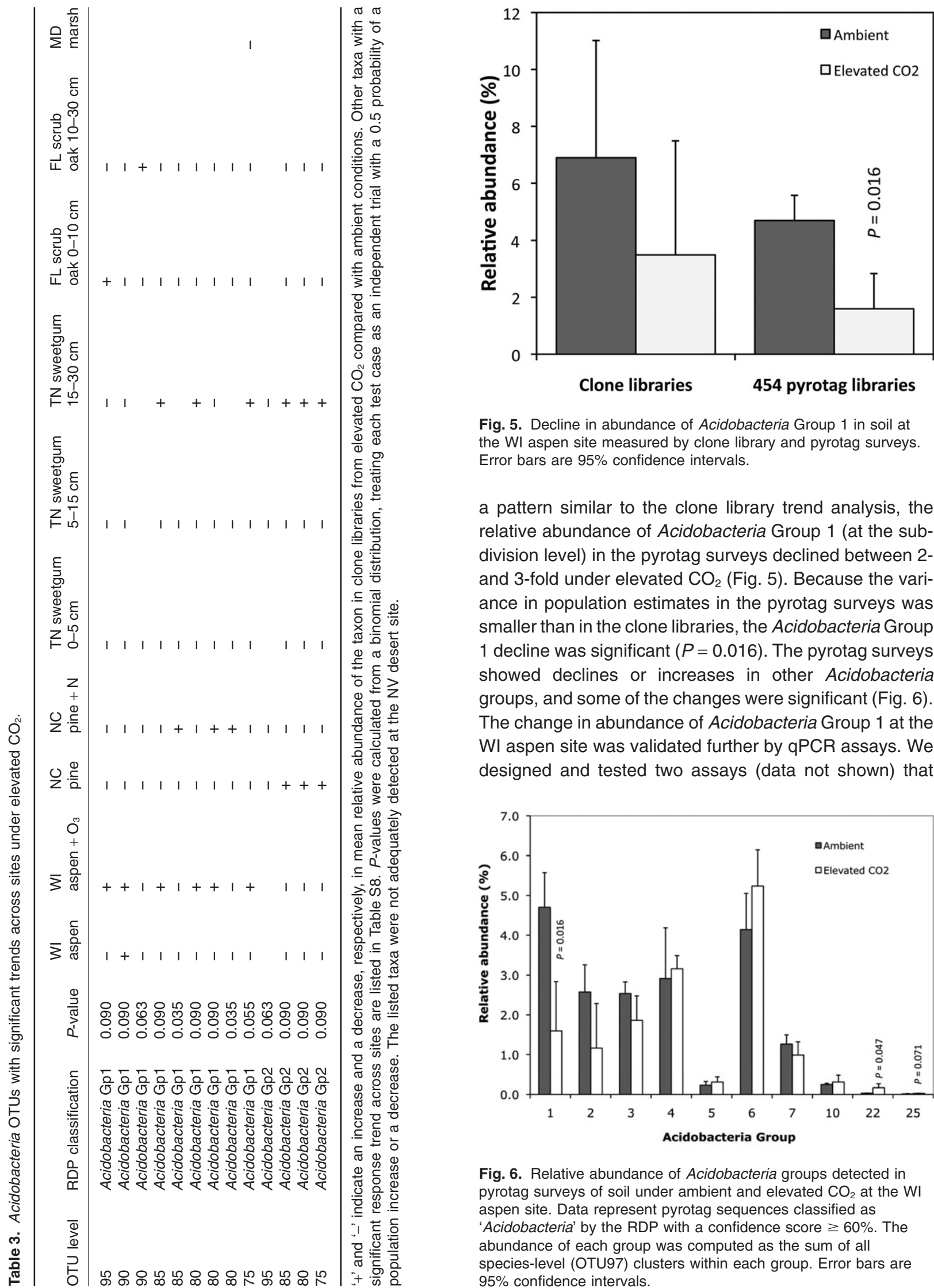

Fig. 5. Decline in abundance of Acidobacteria Group 1 in soil at the $\mathrm{Wl}$ aspen site measured by clone library and pyrotag surveys. Error bars are $95 \%$ confidence intervals.

a pattern similar to the clone library trend analysis, the relative abundance of Acidobacteria Group 1 (at the subdivision level) in the pyrotag surveys declined between 2and 3-fold under elevated $\mathrm{CO}_{2}$ (Fig. 5). Because the variance in population estimates in the pyrotag surveys was smaller than in the clone libraries, the Acidobacteria Group 1 decline was significant $(P=0.016)$. The pyrotag surveys showed declines or increases in other Acidobacteria groups, and some of the changes were significant (Fig. 6). The change in abundance of Acidobacteria Group 1 at the WI aspen site was validated further by qPCR assays. We designed and tested two assays (data not shown) that

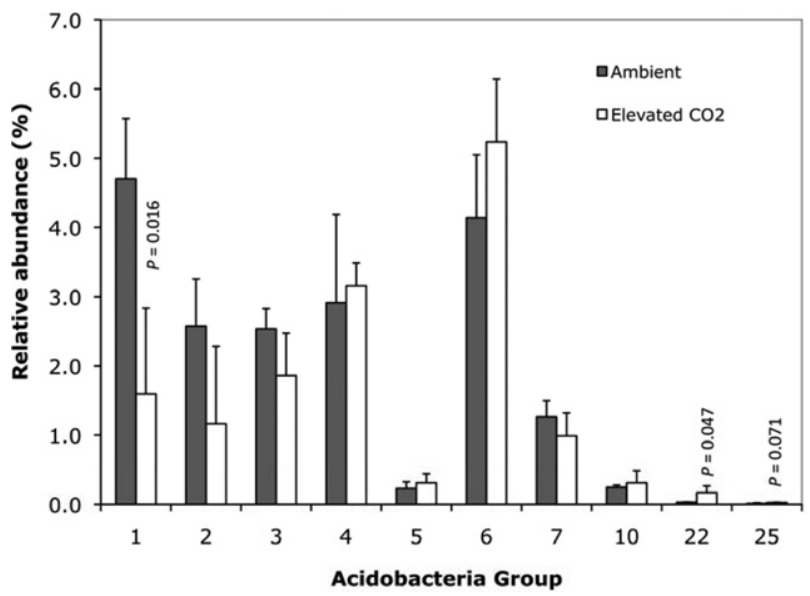

Fig. 6. Relative abundance of Acidobacteria groups detected in pyrotag surveys of soil under ambient and elevated $\mathrm{CO}_{2}$ at the WI aspen site. Data represent pyrotag sequences classified as 'Acidobacteria' by the RDP with a confidence score $\geq 60 \%$. The abundance of each group was computed as the sum of all species-level (OTU97) clusters within each group. Error bars are $95 \%$ confidence intervals. 
collectively had a predicted coverage of $36 \%$ of the 8430 Acidobacteria Group 1 sequences obtained from the RDP. The assays showed significant $(P<0.006)$ declines between 3- and 4-fold in the abundance of Acidobacteria Group 1 taxa in soil samples under elevated $\mathrm{CO}_{2}$. Based on these results, further analysis of the function and response of Acidobacteria Group 1 under ecosystem exposure to elevated $\mathrm{CO}_{2}$ is warranted.

\section{Discussion}

Predicting climate change impacts requires knowledge of general ecosystem response patterns and their variability. Among six ecosystems, we found patterns in bacterial population responses to a decade of elevated $\mathrm{CO}_{2}$ treatment. About $18 \%$ of the dominant taxa detected in multiple ecosystems displayed significant $(P<0.1)$ cross-site response patterns, wherein the direction of taxon response (i.e. an increase or decrease in relative abundance) under elevated $\mathrm{CO}_{2}$ was more consistent among habitats than expected by chance. Discovering common bacterial response patterns among disparate ecosystems is important because it suggests the occurrence of common mechanistic phenomena under elevated $\mathrm{CO}_{2}$, and it provides a first step towards identifying functional details.

Ongoing efforts to predict whether ecosystems will act as carbon sources or sinks under future climate scenarios are hampered by technical difficulties in characterizing key responses (e.g. changes in soil carbon pools) and by site-specific ecosystem behaviour. Site-specific behaviour yields conflicting observations that cannot be usefully incorporated in climate models. General indicators (biomass, taxon richness and community composition) of microbial community response to climate factors have been highly variable and conflicting among experiments (Lipson et al., 2002; Montealegre et al., 2002; Phillips et al., 2002; Niklaus et al., 2003; Ebersberger et al., 2004; Kandeler et al., 2006; Lipson et al., 2006; Carney et al., 2007; Chung et al., 2007; Denef et al., 2007; Drissner et al., 2007; Lesaulnier et al., 2008; Paterson et al., 2008). We found similar variability in our concerted study. Our results demonstrate that these general community metrics showed ecosystem-specific responses to elevated $\mathrm{CO}_{2}$ treatments, and therefore do not have broad predictive value across a wide range of ecosystems.

The soil bacterial communities were generally resilient despite the array of physical and chemical changes in soil associated with plant responses to elevated $\mathrm{CO}_{2}$. Changes in soil that may provoke microbial responses under elevated $\mathrm{CO}_{2}$ include increased litter deposition (Karnosky, 2003; Lichter et al., 2008; Hoosbeek and ScarasciaMugnozza, 2009), increased litter $\mathrm{C}: \mathrm{N}$ ratios (Cotrufo et al., 1994; Gill et al., 2002; Heath et al., 2005), increased root growth and turnover (King et al., 2001; Larson et al.,
2002; Matamala et al., 2003; Norby et al., 2004; Godbold et al., 2006; Lukac et al., 2009), altered root exudates (Cheng, 1999; Paterson et al., 2008; Pendall et al., 2008; Phillips et al., 2009), changes in root depth distributions (Iversen, 2010), and possible changes in nitrogen demand (Hungate et al., 1994; 1996; Treseder, 2004; Finzi et al., 2007; Haase et al., 2007; Niboyet et al., 2010).

Soil microbial taxa that are potentially responsive to elevated $\mathrm{CO}_{2}$ and other climate change factors have been identified in numerous site-specific studies (Zak et al., 2000; Montealegre et al., 2002; Chung et al., 2005; Moscatelli et al., 2005; Carney et al., 2007; Denef et al., 2007; Drigo et al., 2009; Talhelm et al., 2009; Castro et al., 2010). The taxonomic groups range from species to phyla. Our results add to the growing lists of potentially responsive taxa. We identified bacterial taxa with potentially significant $(P<0.05)$, twofold or greater changes in relative abundance under elevated $\mathrm{CO}_{2}$ in every ecosystem. The observation that only a small fraction (about $2 \%$ ) of the taxa are potentially responsive demonstrates the resilience of the communities. Water, nitrogen deposition and spatial variability appear to influence microbial communities more than ecosystem exposure to elevated $\mathrm{CO}_{2}$ (Bloor et al., 2009; Garten et al., 2009; Ge et al., 2010). Although we cannot generalize across all six sites, soil depth (examined in two ecosystems) and nitrogen deposition (examined in one ecosystem) had larger effects than elevated $\mathrm{CO}_{2}$, significantly affecting 11-12\% (range from $2 \%$ to $21 \%$ ) of the bacterial taxa. A caveat is that the size of the 'responsive' fraction of the bacterial community may depend on where in the abundance distribution most responses occur. Dominant taxa may be less responsive to elevated $\mathrm{CO}_{2}$ effects compared with less abundant taxa. Much deeper surveys or targeted approaches will be needed to address this ambiguity.

The most striking finding in our study was the identification of climate-responsive taxa that showed significant trends in the direction of response ('+' or '-') under elevated $\mathrm{CO}_{2}$ across ecosystems. We looked for consistent directional changes based on the notion that changes in relative abundance within individual ecosystems may be too small or confounded by spatial heterogeneity to be detected by standard statistical comparison of population means. Given the size of our surveys, the trend analysis was restricted to a small number of taxa that were highly abundant at multiple sites. About $18 \%$ of the taxa analysed showed significant directional trends under elevated $\mathrm{CO}_{2}$ (Table S8). Acidobacteria Group 1 displayed the most robust trend across the sites. Members of Acidobacteria Group 1 were detected in two or more replicates in five of the six ecosystems and declined up to 3.5-fold in relative abundance under elevated $\mathrm{CO}_{2}$. The decline in Acidobacteria Group 1 at the WI aspen site was validated by pyrotag surveys (100-fold larger than the clone librar- 
ies) and qPCR assays. Moreover, these higher-quality measurements revealed statistically significant declines that were not apparent in the clone library surveys, illustrating the value of deeper coverage and more targeted detection strategies in quantifying responses. The value of identifying indicator taxa for community response to climate change factors cannot be overstated. Given a set of indicator genes or species, targeted studies that clarify spatial and temporal responses are feasible at lower cost and higher resolution.

The ecological significance of the observed Acidobacteria Group 1 response trend is unknown. The environmental abundance of Acidobacterium Group 1 is generally expected to decline as $\mathrm{pH}$ (Sait et al., 2006; Eichorst et al., 2007; Hartman et al., 2008; Upchurch et al., 2008; Jones et al., 2009; Lauber et al., 2009) and carbon supply (Fierer et al., 2007) increase. Both effects are conceivable under elevated $\mathrm{CO}_{2}$. Soil pH can increase via decomposition of organic acids (Rukshana et al., 2011), decomposition of organic matter low in nitrogen (Kretzschmar et al., 1991; Barekzai and Mengel, 1992), plant/microbial release of conjugate bases ( $\mathrm{Li}$ et al., 2008), or production of $\mathrm{NH}_{3}$ from organic matter decomposition (Ingelog and Nohrstedt, 1993). Increased carbon supply seems a logical consequence of increased plant productivity, and has been supported by observed increases in microbial growth rates in three long-term $\mathrm{CO}_{2}$ enrichment experiments (Blagodatskaya et al., 2010). Increased carbon supply is predicted to provoke contrasting responses of bacterial phyla rich in oligotrophs (e.g. Acidobacteria) versus copiotrophs (Fierer et al., 2007). We did not find ample evidence for this response model. A robust trend of increases in copiotrophic taxa was not observed (Table S8). In fact, the most robust trend contrasting with the decline of Acidobacteria Group 1 was an increase in Caulobacteriales, an Alpha-proteobacteria order known to contain oligotrophs. Thus, the functional significance of these responses under elevated $\mathrm{CO}_{2}$ requires further investigation.

In conclusion, our screen for dominant taxa responsive to elevated $\mathrm{CO}_{2}$ treatments in six ecosystems may be only the tip of the iceberg. Less abundant taxa may be more sensitive to physico-chemical gradients and therefore more dynamic in response to climate factors. If this hypothesis is true, deeper sequencing beyond the 100fold increase achieved with 454 pyrotag sequencing could reveal more dynamic responses of microbial communities to climate factors.

\section{Experimental procedures}

\section{Sample collection}

Soil cores were collected from four Free Air $\mathrm{CO}_{2}$ Enrichment (FACE) field research sites and two Open Top Chamber
(OTC) sites. Site characteristics and site nomenclature used in this study are provided in Tables 1 and S1. Samples were collected between 2007 and 2008 (Table S1). Three to ten soil cores from random locations in a FACE ring or OTC chamber were obtained from the upper $5-10 \mathrm{~cm}$ (depending on the site), homogenized, and stored at $-70^{\circ} \mathrm{C}$ for subsequent molecular analysis. At the NV desert site, separate sets of samples were collected from shrub rhizospheres and interspace biocrusts. At the FL scrub oak and TN sweetgum sites, $30 \mathrm{~cm}$ deep soil cores were obtained for analysis of depth profiles and sectioned into multiple strata before homogenization and DNA extraction. For physical and chemical characterization, two portions of the soil samples were sieved with a $2 \mathrm{~mm}$ sieve, dried for 1 week, and sent to the New Mexico State Soil, Water, and Agricultural Testing Lab (http:// swatlab.nmsu.edu/) for chemical analysis.

\section{DNA extraction}

DNA was extracted from duplicate $0.25 \mathrm{~g}$ (TN sweetgum) or $0.5 \mathrm{~g}$ (all other sites) soil samples using the MP Biomedical FastDNA Spin Kit and duplicates were pooled. These FastDNA extracts were used to assess changes in soil biomass (DNA concentration) or bacterial biomass (Q-PCR assay) across all six sites. Additionally, soil samples from four sites (WI aspen, NC pine, NV desert and TN sweetgum sites) were extracted using MoBio PowerSoil DNA Isolation Kit. For 16S rRNA gene clone library construction, the FastDNA extracts were used for all sites except the WI aspen, NC pine and TN sweetgum sites. At these three sites, the MoBio extracts were used for clone library construction, in accordance with prior practices at these sites. For each kit, the manufacturer's protocol was followed. DNA extracts were examined on $1.2 \%$ agarose gels in $0.5 \times$ Tris-borate-EDTA (TBE) with ethidium bromide and quantified using the Quant-It PicoGreen dsDNA Assay Kit (Invitrogen).

Because two different DNA extraction methods were used in this study, we determined the impact these methodological differences might have on cross-site comparisons. We applied both methods in parallel on 12 soil samples from four sites (NV desert, NC pine, TN sweetgum, and WI aspen; Table S11) and examined systematic bias in total DNA recovery and DNA composition. We did not observe a systematic bias of extraction method on bacterial community richness, diversity or composition (Figs S1 and S2). Although the FastDNA method yielded an average of sevenfold higher recovery than the MoBio method (Table S11), this did not influence our ecosystem analyses, because only FastDNA extracts were used to evaluate treatment effects on community biomass.

\section{Clone libraries}

For each soil sample, a 384-member library of 16S rRNA gene clones was created. 16S rRNA gene fragments of 740760 bp were amplified from soil DNA using primers 27F (5'AGAGTTTGATCMTGGCTCAG) (Lane, 1991) and 787Rb (5'-GGACTACNRGGGTATCTAAT) (Kuske et al., 2006). PCR was performed in triplicate for each sample. Each $50 \mu \mathrm{l}$ reaction consisted of $1 \times \mathrm{PCR}$ buffer containing $1.5 \mathrm{mM} \mathrm{MgCl} 2$ 
(Applied Biosystems), $0.2 \mathrm{mM}$ of each dNTP (Applied Biosystems), $1.5 \mathrm{U}$ of Taq LD DNA Polymerase (Applied Biosystems), $1 \mu \mathrm{M}$ of each primer, and $2 \mu$ l of DNA template. Each DNA template was diluted 10 - or 100 -fold in water from the original DNA extract to avoid PCR inhibition. Thermal cycling consisted of $94^{\circ} \mathrm{C}$ for $2 \mathrm{~min} ; 25$ cycles of $94^{\circ} \mathrm{C}$ for $1 \mathrm{~min}, 55^{\circ} \mathrm{C}$ for $1 \mathrm{~min}$, and $72^{\circ} \mathrm{C}$ for $1 \mathrm{~min} ; 72^{\circ} \mathrm{C}$ for $7 \mathrm{~min}$; and $4^{\circ} \mathrm{C}$ storage. Product size was confirmed by gel electrophoresis. Triplicate reactions were pooled, purified (Qiagen QIAquick PCR Purification Kit), and cloned (Invitrogen TOPO TA Cloning Kit). Clones were bidirectionally sequenced with M13 primers using Sanger technology.

\section{Sequence processing}

Forward and reverse sequences were assembled with Sequencher v4.7 (Ann Arbor, MI, USA). Potential chimeras were identified and discarded by Bellerophon (Huber et al., 2004). Remaining sequences were aligned using the ArbSilva automated alignment tool (Pruesse et al., 2007). Aligned sequences were compiled in a single database in ARB (Ludwig et al., 2004).

\section{OTU binning and taxonomic identification}

All 28546 sequences from 97 clone libraries were placed into Operational Taxonomic Units (OTUs) using the completelinkage clustering tool from the Ribosomal Database Project (RDP) (Cole et al., 2009). The output was parsed with a custom-written $\mathrm{C}+$ program into a matrix of OTU counts per sample (Table S12). A representative sequence for each OTU at the 0.01 distance level was classified via the RDP classifier (Wang et al., 2007). The taxonomic assignments were then applied to appropriate OTUs defined at distance thresholds of $0.03,0.05,0.1,0.15,0.2,0.25$ and 0.3 .

\section{Data analysis}

Rarefaction, calculation of sample dissimilarity matrices, and nonmetric multidimensional scaling were performed using functions in the Vegan package 1.15-4 (Oksanen et al., 2009) in the R statistical computing platform for Mac v2.9.2 (Team, 2009). Other analyses were performed in Microsoft Excel. For trend analyses, the probability of obtaining $\geq n$ outcomes in $m$ independent trials was computed from a binomial probability distribution. UniFrac tests for homogeneity of clone libraries were performed using the web-based FastUniFrac tool (Hamady et al., 2010). The false discovery rate correction for multiple testing (Yoav and Yekutieli, 2001) was performed using the $\mathrm{R}$ software package (http://www.rproject.org/).

\section{Bacterial 16S rRNA gene quantitative PCR}

Primers EUB 338 and EUB 518 (Lane, 1991) were used for qPCR of the bacterial 16S rRNA gene. Soil DNA samples were adjusted to $3-25 \mathrm{ng} \mathrm{ml}^{-1}$ in $1 \times$ Tris-EDTA (TE). Each PCR was performed in triplicate as described in Castro and colleagues (Castro et al. 2010). Each $30 \mu \mathrm{l}$ reaction con- tained $15 \mu \mathrm{l}$ of $\mathrm{iQ}$ SYBR Green Supermix (Bio-Rad Laboratories), $1.25 \mathrm{mg} \mathrm{ml}^{-1} \mathrm{BSA}$ (Roche Diagnostics $\mathrm{GmbH}$ ), $1 \mathrm{ml}$ of soil DNA and $133 \mathrm{nM}$ of each primer. Thermal cycling conditions were as follows: one cycle of $95^{\circ} \mathrm{C}$ for $3.25 \mathrm{~min}$; 40 cycles of $95^{\circ} \mathrm{C}$ for $15 \mathrm{~s}, 55^{\circ} \mathrm{C}$ for $30 \mathrm{~s}$, and $72^{\circ} \mathrm{C}$ for $30 \mathrm{~s}$; one cycle of $95^{\circ} \mathrm{C}$ for $1 \mathrm{~min} ; 80$ cycles of $55^{\circ} \mathrm{C}$ for $10 \mathrm{~s} ; 4^{\circ} \mathrm{C}$ storage. Reactions were performed with a MyiQ Real-Time PCR machine (Bio-Rad Laboratories).

Quantitative DNA standards for qPCR were produced from an Escherichia coli 16S rRNA gene. A gene fragment was PCR amplified from E. coli DNA using primers 27F and $787 \mathrm{Rb}$. Triplicate reactions were performed, pooled, purified and cloned as described for clone libraries (above). E. coli clones with inserts of correct size were confirmed by PCR with M13 primers. Suitable E. coli clones were grown overnight at $37^{\circ} \mathrm{C}$ in Luria-Bertani (LB) broth containing $50 \mathrm{mg} \mathrm{ml}^{-1}$ of carbenicillin. Plasmid DNA was extracted using the QIAprep Spin Miniprep Kit (Qiagen) and confirmed by gel electrophoresis. Plasmid DNA was linearized by digestion with Scal (New England Biolabs) at $37^{\circ} \mathrm{C}$ for $2 \mathrm{~h}$ followed by enzyme inactivation at $80^{\circ} \mathrm{C}$ for $20 \mathrm{~min}$. The $4716 \mathrm{bp}$ DNA was gel-purified, quantified using the quant-it PicoGreen dsDNA Assay kit (Invitrogen), and a dilution series was prepared for use as standards.

\section{S rRNA gene pyrotag sequencing}

16S rRNA gene pyrotag data were obtained for 12 soil DNA samples from the WI aspen site. Pyrotag libraries targeting the hypervariable regions V6-V8 were constructed using universal primers 926F and 1392R (Kunin et al., 2010) and were sequenced using the 454-titanium platform and standard protocols (Engelbrektson et al., 2010). PCR reactions and product purification were performed as described above. The sequences were binned into OTUs at the $97 \%$ sequence similarity level and a representative sequence of each OTU was taxonomically classified via the RDP.

\section{Quantitative PCR for Acidobacteria Group 1}

Quantitative PCR was performed using the Biorad iQ SyBr Green Supermix and two primer sets designed for specific detection of Acidobacteria Group 1. The two primer sets were: (i) acidoG1_8.2 (5'-GGTGCGTGGAATTCCCGG, 5'-GCGGATTGCTTATCGCGTTAG), and (ii) acidoG1_8.17 (5'-CCCTTGGGACGTAAACTCCTT, TTCCACGCACCTCTC CCA). Each assay was performed in triplicate with primers at $0.2 \mathrm{mM}$ and $1 \mathrm{ng}$ of soil DNA per reaction. Cycling conditions were as follows: one cycle of $94^{\circ} \mathrm{C}$ for $5 \mathrm{~min}$; 40 cycles of $94^{\circ} \mathrm{C}$ for $15 \mathrm{~s}, 65^{\circ} \mathrm{C}$ for $30 \mathrm{~s} ; 91$ cycles of $50^{\circ} \mathrm{C}$ for $30 \mathrm{~s} ; 4^{\circ} \mathrm{C}$ storage. Melt curves were generated for every run to detect potential false positives. Standard curves were generated with purified, genomic DNA from Acidobacterium capsulatum.

\section{GenBank accession numbers}

Representative bacterial 16S rRNA gene clone sequences were deposited in GenBank with Accession No. JQ366086JQ387568. 


\section{Acknowledgements}

This work was supported by the U.S. Department of Energy (DOE), Office of Science, Biological and Environmental Research Program, through a Science Focus Area grant to C.R.K. and J.M.D. (2009LANLF260). Sanger and 454 titanium pyrosequencing were conducted by the U.S. DOE Joint Genome Institute. The six elevated $\mathrm{CO}_{2}$ research sites in this study were supported by the U.S. DOE Office of Science, Biological and Environmental Research Program. The authors thank Yvonne Rogers and Shannon Johnson for their technical assistance, Lawrence Ticknor for statistics consultation, and many people at the six field sites for site access and technical support.

\section{References}

Ainsworth, E.A., and Long, S.P. (2005) What have we learned from 15 years of free-air $\mathrm{CO}_{2}$ enrichment (FACE)? A metaanalytic review of the responses of photosynthesis, canopy properties and plant production to rising $\mathrm{CO}_{2}$. New Phytol 165: 351-372.

Ainsworth, E.A., and Rogers, A. (2007) The response of photosynthesis and stomata conductance to rising $\mathrm{CO}_{2}$ : mechanisms and environmental interactions. Plant Cell Environ 30: 258-270.

Barekzai, A., and Mengel, K. (1992) Effect of microbial decomposition of mature leaves on soil $\mathrm{pH}$. J Plant Nutr Soil Sci 156: 93-94.

Blagodatskaya, E., Blagodatsky, S., Dorodnikov, M., and Kuzyakov, Y. (2010) Elevated atmospheric $\mathrm{CO}_{2}$ increases microbial growth rates in soil: results of three $\mathrm{CO}_{2}$ enrichment experiments. Glob Change Biol 16: 836-848.

Bloor, J.M.G., Niboyet, A., Leadley, P.W., and Barthes, L. (2009) $\mathrm{CO}_{2}$ and inorganic $\mathrm{N}$ supply modify competition for $\mathrm{N}$ between co-occurring grass plants, tree seedlings and soil microorganisms. Soil Biol Biochem 41: 544-552.

Carney, K.M., Hungate, B.A., Drake, B.G., and Megonigal, J.P. (2007) Altered soil microbial community at elevated $\mathrm{CO}_{2}$ leads to loss of soil carbon. PNAS 104: 4990-4995.

Castro, H.F., Classen, A.T., Austin, E.E., Norby, R.J., and Schadt, C.W. (2010) Soil microbial community responses to multiple experimental climate change drivers. Appl Environ Microbiol 76: 999-1007.

Cheng, W.X. (1999) Rhizosphere feedbacks in elevated $\mathrm{CO}_{2}$. Tree Physiol 19: 313-320.

Chung, H., Zak, D.R., and Lilleskov, E.A. (2005) Fungal community composition and metabolism under elevated $\mathrm{CO}_{2}$ and O3. Oecologia 147: 143-154.

Chung, H., Zak, D.R., Reich, P.B., and Ellsworth, D.S. (2007) Plant species richness elevated $\mathrm{CO}_{2}$, and atmospheric nitrogen deposition alter soil microbial community composition and function. Glob Change Biol 13: 1-10.

Cole, J.R., Wang, Q., Cardenas, E., Fish, J., Chai, B., Farris, R.J., et al. (2009) The Ribosomal Database Project: improved alignments and new tools for rRNA analysis. Nucleic Acids Res 37(Database issue): D141-D145.

Cotrufo, M.F., Ineson, P., and Rowland, A.P. (1994) Decomposition of tree leaf litters grown under elevated $\mathrm{CO}_{2}$ : effect of litter quality. Plant Soil 163: 121-130.
Couteaux, M.-M., Bottner, P., and Berg, B. (1995) Litter decomposition, climate and litter quality. Trends Ecol Evol 10: $62-66$.

Denef, K., Bubenheim, H., Lenhart, K., Vermeulen, J., Cleemput, O.V., Boeckx, P., and Muller, C. (2007) Community shifts and carbon translocation within metabolically-active rhizosphere microorganisms in grasslands under elevated $\mathrm{CO}_{2}$. Biogeosciences 4: 769-779.

Drigo, B., van Veen, J.A., and Kowalchuk, G.A. (2009) Specific rhizosphere bacterial and fungal groups respond differently to elevated atmospheric $\mathrm{CO}_{2}$. ISME J 3: 12041217.

Drissner, D., Blum, H., Tscherko, D., and Kandeler, E. (2007) Nine years of enriched $\mathrm{CO}_{2}$ changes the function and structural diversity of soil microorganisms in a grassland. Eur J Soil Sci 58: 260-269.

Dunbar, J., Valdez, Y., and Beck, N. (2006) DHS NBFAC Final Technical Progress Report: nucleic acids extraction using novel PCR inhibitor removal reagents. Los Alamos National Laboratory Unclassified Document 11-11573.

Ebersberger, D., Wermbter, N., Niklaus, P.A., and Kandeler, E. (2004) Effects of long term $\mathrm{CO}_{2}$ enrichment on microbial community structure in calcareous grassland. Plant Soil 264: 313-323.

Eichorst, S.A., Breznak, J.A., and Schmidt, T.M. (2007) Isolation and characterization of soil bacteria that define Terriglobus gen. nov., in the phylum Acidobacteria. Appl Environ Microbiol 73: 2708-2717.

Engelbrektson, A., Kunin, V., Wrighton, K.C., Zvenigorodsky, N., Chen, F., Ochman, H., and Hugenholtz, P. (2010) Experimental factors affecting PCR based estimates of microbial species richness and evenness. ISME J 4: 642-647.

Fierer, N., Bradford, M.A., and Jackson, R.B. (2007) Toward an ecological classification of soil bacteria. Ecology $\mathbf{8 8}$ : 1354-1364.

Finzi, A.C., Norby, R.J., Calfapietra, C., Gallet-Budynek, A., Gielen, B., Holmes, W.E., et al. (2007) Increases in nitrogen uptake rather than nitrogen-use efficiency support higher rates of temperate forest productivity under elevated $\mathrm{CO}_{2}$. PNAS 104: 14014-14019.

Garten, C.T., Classen, A.T., and Norby, R.J. (2009) Soil moisture surpasses elevated $\mathrm{CO}_{2}$ and temperature as a control on soil carbon dynamics in a multi-factor climate change experiment. Plant Soil 319: 85-94.

Ge, Y., Chen, C., Xu, Z., Oren, R., and He, J.-Z. (2010) The spatial factor, rather than elevated $\mathrm{CO}_{2}$, controls the soil bacterial community in a temperate forest ecosystem. Appl Environ Microbiol 76: 7429-7436.

Gill, R.A., Polley, H.W., Johnson, H.B., Anderson, L.J., Maherali, H., and Jackson, R.B. (2002) Nonlinear grassland responses to past and future atmospheric $\mathrm{CO}_{2}$. Nature 417: 279-282.

Godbold, D.L., Hoosbeek, M.R., Lukac, M., Cotrufo, M.F., Janssens, I.A., Ceulemans, R., et al. (2006) Mycorrhizal hyphal turnover as a dominant process for carbon input into soil organic matter. Plant Soil 281: 15-24.

Haase, S., Neumann, G., Kania, A., Kuzyakov, Y., Roemheld, V., and Kandeler, E. (2007) Elevation of atmospheric $\mathrm{CO}_{2}$ and $\mathrm{N}$-nutritional status modify nodulation, nodule-carbon supply, and root exudation of Phaseolus vulgaris L. Soil Biol Biochem 39: 2208-2221. 
Hall, M.C., Stiling, P., Hungate, B.A., Drake, B.G., and Hunter, M.D. (2005) Effects of elevated $\mathrm{CO}_{2}$ and herbivore damage on litter quality in a scrub oak ecosystem. $\mathrm{J}$ Chem Ecol 31: 2343-2356.

Hamady, M., Lozupone, C., and Knight, R. (2010) Fast UniFrac: facilitating high-throughput phylogenetic analyses of microbial communities including analysis of pyrosequencing and PhyloChip data. ISME J 4: 17-27.

Hartman, W.H., Richardson, C.J., Vilgalys, R., and Bruland, G.L. (2008) Environmental and anthropogenic controls over bacterial communities in wetland soils. Proc Natl Acad Sci USA 105: 17842-17847.

Heath, J., Ayres, E., Possell, M., Bardgett, R.D., Black, H.I.J., Grant, H., et al. (2005) Rising atmospheric $\mathrm{CO}_{2}$ reduces sequestration of root-derived soil carbon. Science 309: 1711-1713.

Hoosbeek, M.R., and Scarascia-Mugnozza, G.E. (2009) Increased litter build up and soil organic matter stabilization in a poplar plantation after 6 years of atmospheric $\mathrm{CO}_{2}$ enrichment (FACE): final results of POP-EuroFACE compared to other forest FACE experiments. Ecosystems 12: 220-238.

Housman, D.C., Namburg, E., Huxman, T.E., Charlet, T.N., Nowak, R.S., and Smith, S.D. (2006) Increases in desert shrub productivity under elevated carbon dioxide vary with water availability. Ecosystems 9: 374-385.

Huber, T., Faulkner, G., and Hugenholtz, P. (2004) Bellerophon: a program to detect chimeric sequences in multiple sequence alignments. Bioinformatics 20: 2317-2319.

Hungate, B.A., Canadell, H., Zhong, H., Chapin, F.S., III, and Holland, E.A. (1994) Elevated atmospheric $\mathrm{CO}_{2}$ increases microbial nitrogen-demand, but plants outcompete microbes for inorganic N. Bulletin of the Ecol Soc America. United States: 101.

Hungate, B.A., Canadell, J., and Chapin, F.S. (1996) Plant species mediate changes in soil microbial $\mathrm{N}$ in response to elevated $\mathrm{CO}_{2}$. Ecology 77: 2505-2515.

Ingelog, T., and Nohrstedt, H.O. (1993) Ammonia formation and soil $\mathrm{pH}$ increase caused by decomposition fruitbodies of macrofungi. Oecologia 93: 449-451.

Iversen, C.M., Ledford, J., and Norby, R.J. (2008) $\mathrm{CO}_{2}$ enrichment increases carbon and nitrogen input from fine roots in a deciduous forest. New Phytol 179: 837-847.

Iversen, I. (2010) Digging deeper: fine-root responses to rising atmospheric $\mathrm{CO}_{2}$ concentration in forested ecosystems. New Phytol 186: 346-357.

Jones, R.T., Robeson, M.S., Lauber, C.L., Hamady, M., Knight, R., and Fierer, N. (2009) A comprehensive survey of soil acidobacterial diversity using pyrosequencing and clone library analyses. ISME J 3: 442-453.

Kandeler, E., Mosier, A.R., Morgan, J.A., Milchunas, D.G., King, J.Y., Rudolph, S., and Tscherko, D. (2006) Response of soil microbial biomass and enzyme activities to the transient elevation of carbon dioxide in a semi-arid grassland. Soil Biol Biochem 38: 2448-2460.

Karnosky, D.F. (2003) Impacts of elevated atmospheric $\mathrm{CO}_{2}$ on forest trees and forest ecosystems: knowledge gaps. Environ Int 29: 161-169.

Kelly, J.J., Bansal, A., Winkleman, J., Janus, L.R., Hell, S., Wencel, M., et al. (2010) Alteration of microbial communities colonizing leaf litter in a temperate woodland stream by growth of trees under conditions of elevated atmospheric $\mathrm{CO}_{2}$. Appl Environ Microbiol 76: 4950-4959.

King, J.S., Pregitzer, K.S., Zak, D.R., Sober, J., Isebrands, J.G., Dickson, R.E., et al. (2001) Fine-root biomass and fluxes of soil carbon in young stands of paper birch and trembling aspen as affected by elevated atmospheric $\mathrm{CO}_{2}$ and tropospheric $\mathrm{O}_{3}$. Oecologia 128: 237-250.

Kretzschmar, R.M., Hafner, H., Bationo, A., and Marschner, $\mathrm{H}$. (1991) Long- and short-term effects of crop residues on aluminium toxicity, phosphorus availability and growth of pearl millet in an acid sandy soil. Plant Soil 136: 215223.

Kunin, V., Engelbrektson, A., Ochman, H., and Hugenholtz, P. (2010) Wrinkles in the rare biosphere: pyrosequencing errors can lead to artificial inflation of diversity estimates. Environ Microbiol 12: 118-123.

Kuske, C.R., Barns, S.M., Grow, C.C., Merrill, L., and Dunbar, J. (2006) Environmental Survey for four pathogenic bacteria and closely related species using phylogenetic and functional genes. J Forensic Sci 51: 548-558.

Lane, D. (1991) 16S/23S Rrna Sequencing. In Nucleic Acid Techniques in Bacterial Systematics. E. Stackebrandt, and M. Goodfellow (eds). New York, NY, USA: John Wiley \& Sons, pp. 115-175.

Larson, J.L., Zak, D.R., and Sinsabaugh, R.L. (2002) Etracellular enzyme activity beneath temperate trees growing under elevated carbon dioxide and ozone. Soil Sci Soc Am J 66: 1848-1856.

Lauber, C.L., Hamady, M., Knight, R., and Fierer, N. (2009) Pyrosequencing-based assessent of soil $\mathrm{pH}$ as a predictor of soil bacterial community structure at the continental scale. Appl Environ Microbiol 75: 5111-5120.

Lesaulnier, S., Papamichail, D., McCorkle, S., Ollivier, B., Skiena, S., Taghavi, S., et al. (2008) Elevated atmospheric $\mathrm{CO}_{2}$ affects soil microbial diversity associated with trembling aspen. Environ Microbiol 10: 926-941.

Li, Z.A., Zou, B., Xia, H.P., Ding, Y.Z., Tan, W.N., and Fu, S.L. (2008) Role of low-molecule-weight organic acids and their salts in regulating soil $\mathrm{pH}(-1)$. Pedosphere 18: 137148.

Lichter, J., Billings, S.A., Ziegler, S., Gaindh, D., Ryals, R., Finzi, A.C., et al. (2008) Soil carbon sequestration in a pine forest after 9 years of atmospheric $\mathrm{CO}_{2}$ enrichment. Glob Change Biol 15: 2910-2922.

Lipson, D.A., Schadt, C.W., and Schmidt, S.K. (2002) Changes in microbial community structure and function in an alpine dry meadow following spring snow melt. Microb Ecol 43: 307-314.

Lipson, D.A., Blair, M., Barron-Gafford, G., Brieve, K., and Murthy, R. (2006) Relationships between microbial community structure and soil processes under elevated atmospheric carbon dioxide. Microb Ecol 51: 302-314.

Ludwig, W., Strunk, O., Westram, R., Richter, L., Meier, H., Yadhukumar, et al. (2004) ARB: a software environment for sequence data. Nucleic Acids Res 32: 1363-1371.

Lukac, M., Lagomarsino, A., Moscatelli, M.C., Angelis, P.D., Cotrufo, M.F., and Godbold, D.L. (2009) Forest soil carbon cycle under elevated $\mathrm{CO}_{2}$ - a case of increased throughput? Forestry 82: 75-86.

Matamala, R., Gonzàlez-Meler, M.A., Jastrow, J.D., and Schlesinger, W.H. (2003) Impacts of fine root turnover on 
forest NPP and soil C sequestration potential. Science 302: 1385-1387.

Montealegre, C.M., van Kessel, C., and Russelle, M.P. (2002) Changes in microbial activity and composition in a pasture ecosystem exposed to elevated atmospheric carbon dioxide. Plant Soil 243: 197-207.

Moscatelli, M.C., Lagomarsino, A., De Angelis, P., and Grego, S. (2005) Seasonality of soil biological properties in a poplar plantation growing under elevated atmospheric $\mathrm{CO}_{2}$. Appl Soil Ecol 30: 162-173.

Niboyet, A., Barthes, L., Hungate, B.A., Roux, X.L., Bloor, J.M.G., Ambroise, A., et al. (2010) Responses of soil nitrogen cycling to the interactive effects of elevated $\mathrm{CO}_{2}$ and inorganic N supply. Plant Soil 327: 35-47.

Niklaus, P.A., Alphei, D., Ebersberger, D., Kampichler, C., Kandeler, E., and Tscherko, D. (2003) Six years of in situ $\mathrm{CO}_{2}$ enrichment evoke changes in soil structure and soil biota of nutrient-poor grassland. Glob Change Biol 9: 585600.

Norby, R.J., Ledford, J., Reilly, C.D., Miller, N.E., and O'Neill, E.G. (2004) Fine-root production dominates response of a deciduous forest to atmospheric $\mathrm{CO}_{2}$ enrichment. PNAS 101: 9689-9693.

Nowak, R.S., Zitzer, S.F., BAbcock, D., Smith-Longozo, V., Charlet, T.N., Coleman, J.S., et al. (2004) Elevated atmospheric $\mathrm{CO}_{2}$ does not conserve water in the Mojave desert. Ecology 85: 93-99.

Oksanen, J., Kindt, R., Legendre, P., O’Hara, B., Simpson, G.L., Solymos, P., et al. (2009) vegan: Community Ecology Package.

Parsons, W.F., Bockheim, J.G., and Lindroth, R.L. (2008) Independent, interactive and species-specific responses to leaf litter decomposition to elevated $\mathrm{CO}_{2}$ and $\mathrm{O}_{3}$ in a Northern hardwood forest. Ecosystems 11: 505519.

Paterson, E., Osler, G., Dawson, L.A., Gebbing, T., Sim, A., and Ord, B. (2008) Labile and recalcitrant plant fractions are utilised by distinct microbial communities in soil: independent of the presence of roots and mycorrhizal fungi. Soil Biol Biochem 40: 1103-1113.

Pendall, E., Rustad, L., and Schimel, J. (2008) Towards a predictive understanding of belowground process responses to climate change: have we moved any closer. Funct Ecol 22: 937-940.

Phillips, R.L., Zak, D.R., Homes, W.E., and White, D.C. (2002) Microbial community composition and function beneath temperate trees exposed to elevated atmospheric carbon dioxide and ozone. Oecologia 131: 236-244.

Phillips, R.P., Berhardt, E.S., and Schlesinger, W.H. (2009) Elevated $\mathrm{CO}_{2}$ increases root exudation from loblolly pine (Pinus taeda) seedlings as an $\mathrm{N}$-mediated response. Tree Physiol 29: 1513-1523.

Pruesse, E., Quast, C., Knittel, K., Fuchs, B., Ludwig, W., Peplies, J., and Glockner, F. (2007) SILVA: a comprehensive online resource for quality checked and aligned ribosomal RNA sequence data compatible with ARB. Nucleic Acids Res 35: 7188-7196.

Randlett, D.L., Pregitzer, K.S., and Curtis, P.S. (1996) Elevated atmospheric carbon dioxide and leaf litter chemistry: influences on microbial respiration and net nitrogen mineralization. Soil Sci Soc Am J 60: 1571-1577.
Rukshana, F., Butterly, C.R., Baldock, J.A., and Tang, C. (2011) Model organic compounds differ in their effects on $\mathrm{pH}$ changes of two soils differing in initial $\mathrm{pH}$. Biol Fert Soils 47: 51-62.

Rustad, L.E., Campell, J.L., Marion, G.M., Norby, R.J., Mitchell, M.J., Hartley, A.E., et al. (2001) A meta-analysis of the response of soil respiration, net nitrogen mineralization, and aboveground plant growth to experimental ecosystem warming. Oecologia 126: 543-562.

Sait, M., Davis, K.E.R., and Janssen, P.H. (2006) Effect of pH on isolation of distribution of members of subdivision 1 of the Phylum Acidobacteria occurring in soil. Appl Environ Microbiol 72: 1852-1857.

Smith, S.D., Huxman, T.E., Zitzer, S.F., Charlet, T.N., Housman, D.C., Coleman, J.S., et al. (2000) Elevated $\mathrm{CO}_{2}$ increases productivity and invasive species success in an arid ecosystem. Nature 408: 79-82.

Talhelm, A.F., Pregitzer, K.S., and Zak, D.R. (2009) Speciesspecific responses to atmospheric carbon dioxide and tropospheric ozone mediate changes in soil carbon. Ecol Lett 12: $1219-1228$.

Team, R.D.C. (2009) R: A Language and Environment for Statistical Computing. Vienna, Austria: R Foundation for Statistical Computing.

Treseder, K.K. (2004) A meta-analysis of mycorrhizal responses to nitrogen, phosphorous, and atmospheric $\mathrm{CO}_{2}$ in field studies. New Phytol 164: 347-355.

Upchurch, R., Chi, C.Y., Everett, K., Dyszynski, G., Coleman, D.C., and Whitman, W.B. (2008) Differences in the composition and diversity of bacterial communities from agricultural and forest soils. Soil Biol Biochem 40: 12941305.

Wang, Q., Garrity, G.M., Tiedje, J.M., and Cole, J.R. (2007) Naive Bayesian Classifier for rapid assignment of rRNA sequences into the new bacterial taxonomy. Appl Environ Microbiol 73: 5261-5271.

Weatherly, H.E., Zitzer, S.F., Coleman, J.S., and Arnone, J.A., III (2003) In situ litter decomposition and litter quality in a Mojave Desert ecosystem: effects of elevated atmospheric $\mathrm{CO}_{2}$ and interannual climate variability. Glob Change Biol 9: 1223-1233.

Yoav, B., and Yekutieli, D. (2001) The control of the false discovery rate in multiple testing under dependency. Ann Stat 29: 1165-1188.

Zak, D.R., Pregitzer, K.S., Curtis, P.S., Teeri, J.A., Fogel, R., and Randlett, D.L. (1993) Elevated atmospheric $\mathrm{CO}_{2}$ and feedback between carbon and nitrogen cycles. Plant Soil 151: 105-117.

Zak, D.R., Pregitzer, K.S., King, J.S., and Holmes, W.E. (2000) Elevated atmospheric $\mathrm{CO}_{2}$, fine roots and the response of soil microorganisms: a review and hypothesis. New Phytol 147: 201-222.

\section{Supporting information}

Additional Supporting Information may be found in the online version of this article:

Fig. 1. Impact of DNA extraction method on 16S rRNA gene library similarity. For each method, beta diversity values were 
computed for the three samples from each of four sites, and the global average and 95\% confidence interval (shown in figure) were computed from the 12 beta diversity values. The mean beta diversity for samples from FastDNA extractions was not significantly different from the mean for samples from MoBio extracts at any classification level, demonstrating a lack of systematic bias.

Fig. 2. Impact of DNA extraction method on the beta diversity of $16 \mathrm{~S}$ rRNA gene clone libraries. MoBio Power Soil and the QBiogene FastDNA extraction methods were compared. 'Duplicates' represents seven pairs of libraries that were derived from DNA extracted in two independent trials from the same seven soil samples. 'Within plots' represents libraries that were extracted from independent soil samples from the same field plot.

Table S1. Soil sample collection from six experimental ecosystems.

Table S2. Chemical and physical characterization of soil samples from six ecosystems.

Table S3. Most common taxa at the family/genus level (OTU85) in ambient surface soils across sites.

Table S4. Soil biomass (DNA) and bacterial biomass (qPCR) estimates for soil samples from six ecosystems.
Table S5. Percentage change in community richness and associated $t$-test results.

Table S6. $t$-tests for differences in average community similarity (beta diversity).

Table S7. Responsive taxa with a twofold or greater change in relative abundance in clone libraries and $P$-values $<0.05$.

Table S8. Taxa with significant trends across sites.

Table S9. Richness of Wisconsin aspen pyrotag libraries.

Table S10. Putative responsive taxa from pyrotag surveys of WI aspen site with twofold or greater changes in abundance and $P$-values $<0.05$.

Table S11. Impact of DNA extraction method on DNA recovery.

Table S12. Code for standardization of 16S rRNA gene surveys for composition analysis in R.

Please note: Wiley-Blackwell are not responsible for the content or functionality of any supporting materials supplied by the authors. Any queries (other than missing material) should be directed to the corresponding author for the article. 